Article

\title{
Barnyardgrass Root Recognition Behaviour for Rice Allelopathy
}

\author{
Tingshuang Zhang ${ }^{1,2}$, Bo Fan ${ }^{1,2}$ and Peng Wang ${ }^{1, *}$ (it) \\ 1 Key Laboratory of Forest Ecology and Management, Institute of Applied Ecology, Chinese Academy of \\ Sciences, Shenyang 110016, China; zhangtingshuang15@mails.ucas.ac.cn (T.Z.); fanfan0928@163.com (B.F.) \\ 2 University of Chinese Academy of Sciences, Beijing 100049, China \\ * Correspondence: wangpeng@iae.ac.cn; Tel.: +86-24-8397-0452
}

Received: 19 January 2018; Accepted: 27 March 2018; Published: 29 March 2018

\begin{abstract}
Recent studies have demonstrated that the presence of belowground neighbours induces varied morphological and biochemical responses in plants. Plant allelopathic activity is elicited by the presence of competitor seedlings or competitor root exudates. However, it is unknown whether allelopathy also influences root recognition behaviour in weed-crop interaction. To assess barnyardgrass response to the presence of allelopathic rice roots, we conducted a greenhouse experiment of barnyardgrass-rice mixed culture, including barnyardgrass monoculture, barnyardgrass mixed with the allelopathic rice line PI312777 and barnyardgrass mixed with the nonallelopathic rice cultivar Liaojing-9. Our results showed that the presence of allelopathic rice roots enhanced root allocation and tissue density (RTD) of barnyardgrass, whereas it decreased root biomass, total root length, specific root length (SRL) and topological index (TI), compared to barnyardgrass grown in monoculture; moreover, there was a significant correlation of topological index with root foraging precision and competition. Therefore, the presence of allelopathic rice roots affected the barnyardgrass root morphology, nutrient foraging and competition, suggesting that allelopathy plays a key role in root recognition behaviour of barnyardgrass-rice competitive interaction.
\end{abstract}

Keywords: root recognition; allelopathy; barnyardgrass-rice interaction; nutrient foraging; belowground competition

\section{Introduction}

Roots are pivotal for plant performance because they not only forage for nutrient and water, but they also fix in the soil. For instance, root overproduction in response to nutrient patches is a ubiquitous adaptive strategy to efficiently take up nutrients that can promote plant growth to gain a competitive advantage at a given time [1-3]. Plants can regulate their root systems (belowground competitive traits) through recognition of neighbouring roots [4-6]; hence the growing interest in the study of root recognition behaviour. Nevertheless, how roots recognize neighbouring roots is an open question. Improved knowledge about root recognition is necessary to have a better understanding of plant production in natural and agricultural systems.

Root recognition might be important in altering root function traits of growth and morphology [7]. For instance, compared with monocultures, the overall effect of species mixture treatments on root biomass in natural grassland systems include overproduction, no effect, or underproduction [8]. Specifically, Phaseolus varigaris produced more roots when grown with interspecific neighbouring roots [9], whereas Trifolium repens and Glycine max decreased their root biomass in the presence of owner roots [10,11]. In contrast, no effect of root biomass or length occurred in Avena sativa and Andropogon gerardii $[12,13]$. In addition, neighbouring roots of Glechoma hederacea enhanced root length of Fragaria 
chiloensis, but attracted roots of Fragaria vesca [14,15]. Changes in root morphology rather than biomass allocation of Deschampsia caespitosa were achieved through root exudate-mediated kin recognition [16].

Several hypotheses have been proposed to explain root recognition, such as physical signaling $[17,18]$, chemical signaling (e.g., plant hormones and root exudates) and microorganism mediation [16,19-21]. For instance, the root exudates of barnyardgrass (Echinochloa crus-galli) contain signaling molecules, which can induce the increase in secondary compounds of rice (Oryza sativa) [22,23]. Consequently, O. sativa affect plant growth and competition by releasing allelochemicals and modifying nutrient availability and soil microbial community [21,24]. Rice allelopathy, the phenomenon where growth or metabolic suppression or promotion of neighbour plants is mediated through the allelochemicals of O. sativa [23-25], has been considered as a potential approach to sustainable weed management $[25,26]$. Several studies have documented that $O$. sativa seedlings can inhibit the germination and growth of paddy weeds including E. crus-galli through root exudation of momilactone $\mathrm{A}$ and $\mathrm{B}$, cyclohexenone (3-Isopropyl-5-acetoxycyclohexene-2-one-1) and flavone (5,7,4'-trihydroxy-3', 5' dimethoxyflavone) [24,27, 28], which provide a competitive advantage for the root growth of neighbouring plant species. Conversely, the root exudates of E. crus-galli, containing the allelochemicals of phenolic acids, lactones and derivatives of phthalic acids, can interfere with O. sativa and other plant species [29]. Thus, to unravel the role of root exudates on root recognition behaviour, more mechanistic studies testing more species that take allelopathy of weed-crop systems specifically into account are needed.

E. crus-galli is one of the most noxious weeds in modern agriculture, especially in paddy fields [23]. E. crus-galli has functional traits which enable it to obtain competitive advantage under a range of geographical and climatic conditions [30]. Moreover, E. crus-galli is one of the most serious herbicide-resistant weeds in the world [31], because it has evolved resistance against herbicides since the 1980s. This severity of the issue calls for immediate solutions and an investigation into the biological and ecological mechanisms of its competitiveness with rice. Fortunately, some varieties of O. sativa as PI312777 and Huagan-3 exhibit high allelopathic activity for paddy weeds and herbicide-resistant barnyardgrass [32,33]. Thus, results from root-mediated interactions between allelopathic rice and barnyardgrass enable us to consider this as a new mechanism of root recognition in plants. Hence, to link allelopathy with root recognition would entail conducting monoculture and mixed culture roots experiments in a barnyardgrass-rice system. Yet, to our knowledge, no study so far has been conducted in this way.

In this study, E. crus-galli plants were chosen to investigate how they respond to the presence of allelopathic or nonallelopathic rice root neighbours in relation to root system architecture and morphology, and how these interactions feedback to the nutrient foraging behaviour of roots and competition between E. crus-galli and O. sativa. We studied barnyardgrass root recognition, focusing on the effects of allelopathy by measuring root biomass and root allocation, specific root length, root tissue density and root topological index in plants subjected to different treatments. Our objectives were to examine whether (1) the root proliferation of E. crus-galli is affected by root neighbours; if so, whether (2) these responses are related to the allelopathy of the neighbours; and whether (3) root foraging behaviour is linked to root competition.

\section{Results}

\subsection{Root Proliferation and Morphological Traits}

Root proliferation and allocation of barnyardgrass were significantly affected by rice root neighbours (the allelopathic rice and the nonallelopathic rice) (Table 1, Figure 1). Compared to the control (BYG + BYG), barnyardgrass mixed with the allelopathic and the nonallelopathic rice roots exhibited less root biomass (Figure 1a) and total root length (Figure 1b). Interestingly, the trait values of barnyardgrass root allocation (ratio of root mass to total mass) in the presence of the nonallelopathic rice neighbour were greater than that in the presence of the alleopathic rice neighbour or barnyardgrass monoculture (Figure 1c). 
Table 1. Summary of the effects of species, treatment (monoculture, mixed with nonallelopathic rice or mixed with allelopathic rice) and their interactions on root biomass and allocation and root morphological traits of E. crus-galli according to linear mixed models. The effects of rice allelopathy on barnyardgrass root biomass and allocation and root morphological traits according to $t$-test. The significant effects $(p<0.05)$ are shown in bold.

\begin{tabular}{|c|c|c|c|c|c|c|c|c|c|c|c|c|}
\hline \multirow{2}{*}{ Root Traits } & \multicolumn{3}{|c|}{ Species } & \multicolumn{3}{|c|}{ Treatment } & \multicolumn{3}{|c|}{$\mathbf{S} \times \mathbf{T}$} & \multicolumn{3}{|c|}{ Allelopathy } \\
\hline & df & F-Value & $p$-Value & df & F-Value & $p$-Value & df & F-Value & $p$-Value & $\mathbf{t}$ & df & $p$-Value \\
\hline Root biomass (mg plant ${ }^{-1}$ ) & 4,8 & 4.707 & 0.029 & 2,8 & 93.23 & $<0.001$ & 8,52 & 0.826 & 0.584 & -4.967 & 40 & $<0.001$ \\
\hline Root allocation $(\%)$ & 4,8 & 1.73 & 0.235 & 2,8 & 9.374 & 0.003 & 8,52 & 1.849 & 0.089 & 2.061 & 40 & 0.039 \\
\hline Root length (m) & 4,8 & 3.956 & 0.046 & 2,8 & 57.604 & $<0.001$ & 8,52 & 1.172 & 0.334 & -0.506 & 40 & 0.615 \\
\hline Specific root length $\left(\mathrm{cm} \mathrm{mg}^{-1}\right)$ & 4,8 & 2.417 & 0.133 & 2,8 & 7.291 & 0.015 & 8,52 & 0.853 & 0.562 & -3.254 & 40 & 0.002 \\
\hline Root tissue density $\left(\mathrm{mg} \mathrm{cm}^{-3}\right)$ & 4,8 & 3.166 & 0.076 & 2,8 & 17.142 & 0.001 & 8,52 & 0.762 & 0.637 & 2.289 & 40 & 0.027 \\
\hline Topological index & 4,8 & 0.471 & 0.756 & 2,8 & 11.731 & 0.004 & 8,52 & 4.714 & $<0.001$ & 3.776 & 40 & 0.001 \\
\hline
\end{tabular}



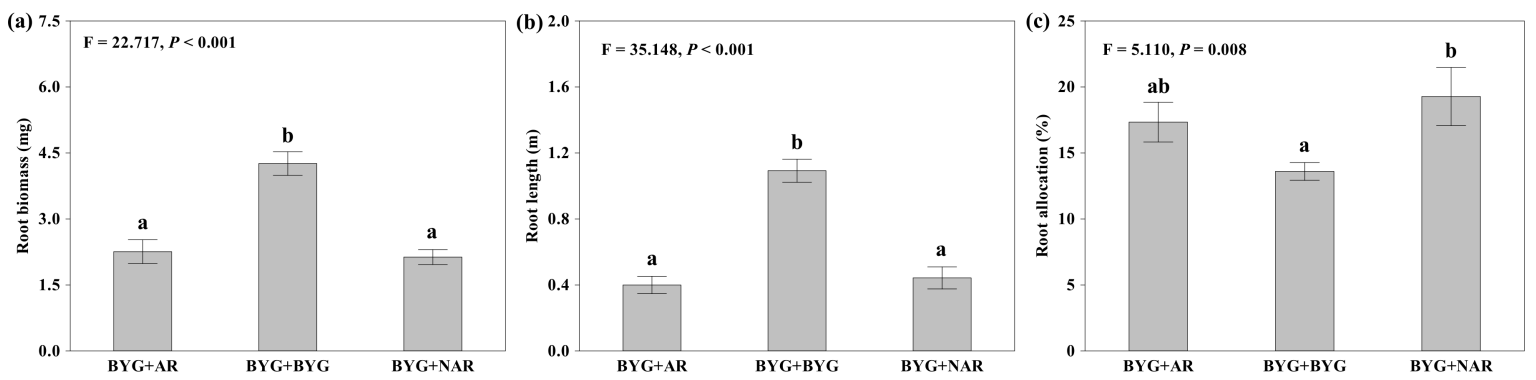

Figure 1. Root biomass (a), root length (b) and root allocation (c) of barnyardgrass grown as a monoculture (BYG + BYG), as mixed cultures with allelopathic rice (BYG + AR) and nonallelopathic rice (BYG + NAR). Each value is the mean \pm SE. Bars with different letters are significantly different at the $p<0.05$ level according to Tukey's test.

The presence of neighbouring rice roots significantly affected barnyardgrass root morphology, with the exception of specific root length (SRL, Figure 2a). Barnyardgrass mixed with allelopathic rice treatment significantly increased average root tissue density (RTD), but decreased the topological index (TI) and SRL (Figure 2b,c). Although the trait values of root proliferation and morphology were affected significantly by species or treatment, all the trait values were not affected by their interaction with the exception for TI (Table 1). Moreover, all the trait values but for root length exhibited significant difference between mixed cultures with allelopathic rice and with nonallelopathic rice (Table 1).
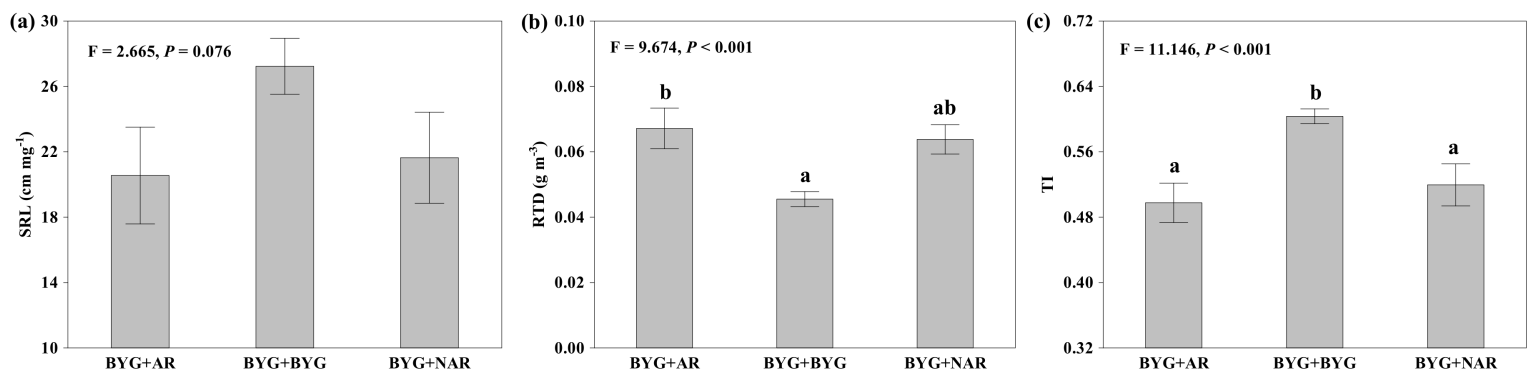

Figure 2. Specific root length (a), root tissue density (b) and topological index (c) on barnyardgrass grown as a monoculture (BYG $+B Y G)$, as mixed cultures with allelopathic rice (BYG $+A R)$ and nonallelopathic rice (BYG + NAR). Each value is the mean \pm SE. Bars with different letters are significantly different at the $p<0.05$ level according to Tukey's test.

\subsection{Root Behaviour of Nutrient Foraging and Competition}

Barnyardgrass root behaviour of nutrient foraging and competition were also significantly affected in response to the presence of rice root neighbours (Figure 3). Root foraging precision was greater in barnyardgrass mixed with the allelopathic rice than in barnyardgrass mixed with the nonallelopathic rice (Figure 3a). Similarly, the competition intensity index (CII $r$, calculated as root dry biomass) was greater in barnyardgrass mixed with the allelopathic rice than in barnyardgrass mixed with the nonallelopathic rice (Figure 3b). However, the effect of rice allelopathy on CIIs (calculated as shoot dry biomass) was not significant (Figure 3c).

There was a significant correlation $(p<0.05)$ of the topological index with root foraging precision and competition, and also a negative correlation of root foraging precision and barnyardgrass root length response to the presence of rice roots neighbours (Figure 4a-c). In contrast, barnyardgrass root foraging precision correlated positively with root competition $(p<0.001$, Figure 4 d). 

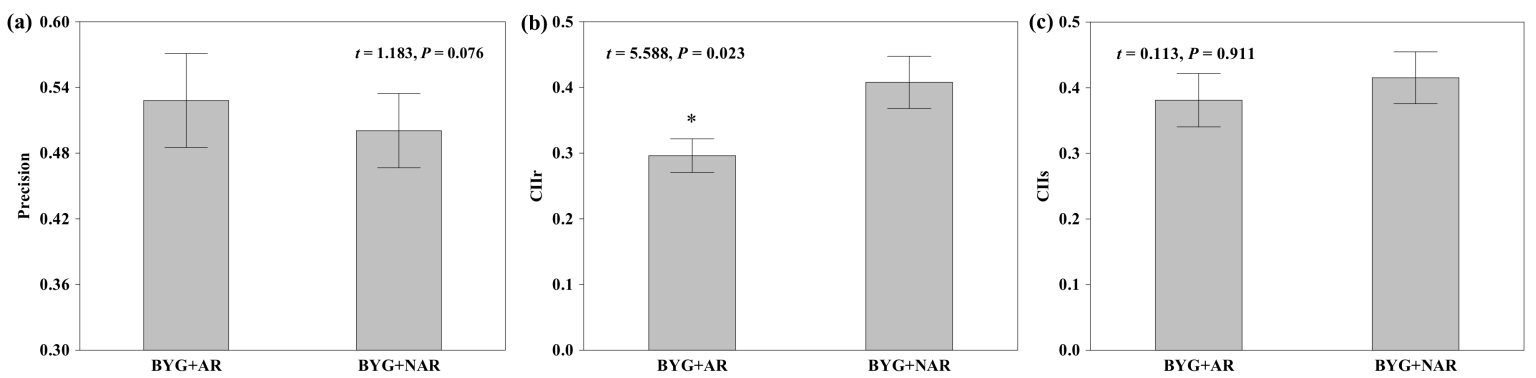

Figure 3. Root foraging precision (a), competition intensity index (CII $r$, b) and (CIIs, c) of barnyardgrass grown as a mixed culture with allelopathic rice (BYG + AR) and nonallelopathic rice (BYG + NAR). Each value is the mean \pm SE. Bars with different letters are significantly different at the $p<0.05$ level according to $t$ test.
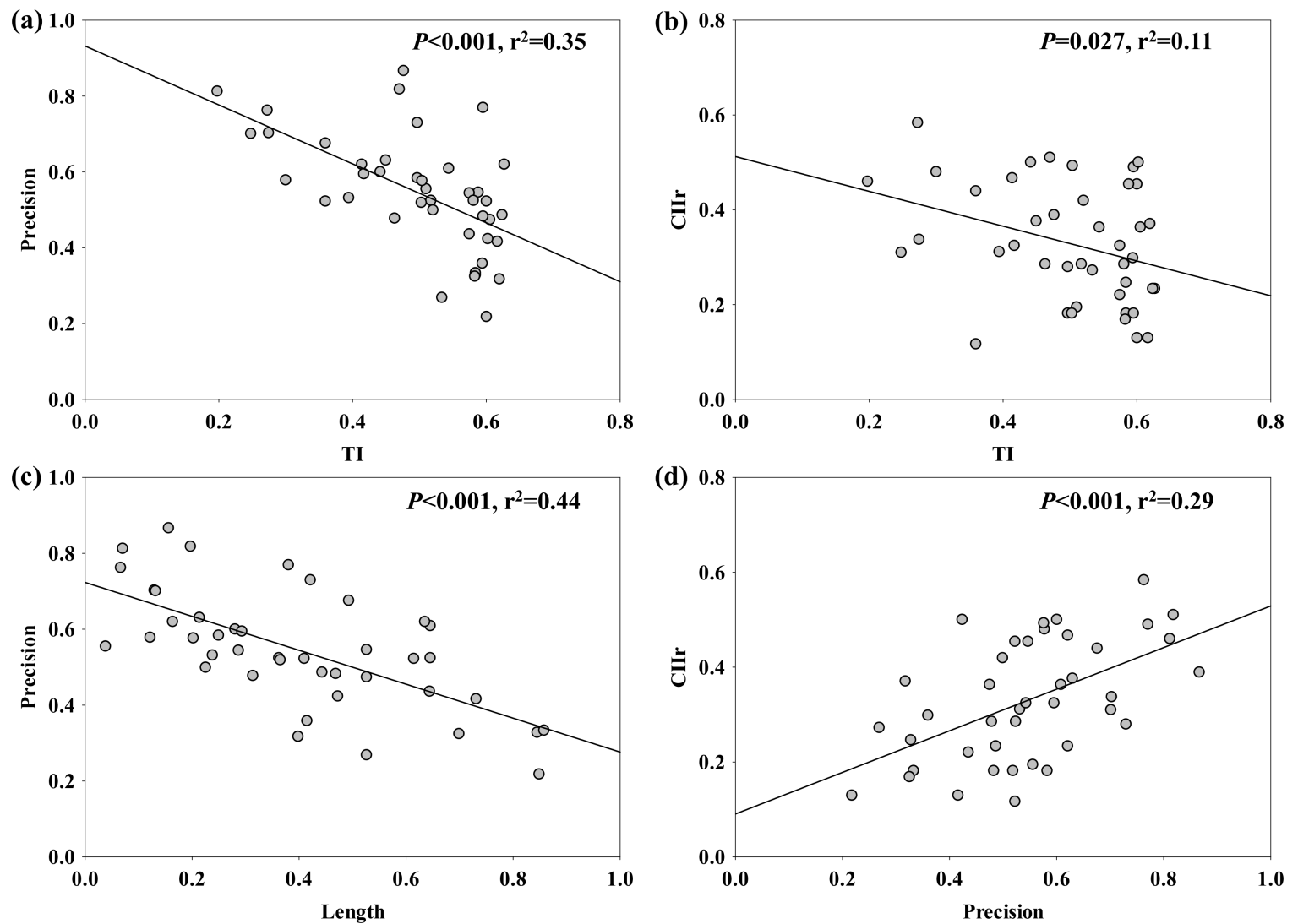

Figure 4. The relationship between barnyardgrass root foraging precision and topological index (a) and root length (c), between competition intensity index (CII $r)$ and $\mathrm{TI}(\mathbf{b})$ and root foraging precision (d). Significant $(p<0.05)$ linear regression lines are shown with the r-square values.

\section{Discussion}

By conducting monoculture/mixed culture roots experiments across a range of allelopathy, we found that barnyardgrass allocated more mass to roots when exposed to neighbouring rice roots (Figure 1). The presence of rice roots enhanced morphological traits of root tissue density (RTD) and reduced the specific root length (SRL) and topological index (TI) of barnyardgrass (Figure 2). The results also showed that the root foraging precision and competition of barnyardgrass were influenced by rice allelopathy (Figure 3), and we observed significant correlations between nutrient foraging and competition (Figure 4). Below, we discuss how root recognition behaviour responses to 
the presence of allelopathic rice roots, and potential mechanisms of root-root competitive interactions between barnyardgrass and allelopathic rice.

\subsection{Root Proliferation Response to Neighbouring Roots of Allelopathic Rice}

Our results confirmed that the presence of rice root neighbours had inhibited barnyardgrass root growth (Figure 1), consequently affecting the morphological (SRL and RTD) and architectural traits (TI) of barnyardgrass (Figure 2). The results are consistent with recent findings that showed both root biomass and allocation of pea declined clearly in response to belowground neighbours [34], indicating that the presence of belowground neighbours can affect plant performance through modifying root traits. One of the possible reasons is that the root size of rice (allelopathic and non-allelopathic rice) was bigger in than in barnyardgrass, resulting in size-asymmetry of belowground competition $[35,36]$. Rice root grows faster than barnyardgrass roots, resulting in more rice biomass and length at early seedling stage when seeded at the same time under the condition of similar soil volume and water content. Our results also determined that the dry weight of the rice roots was two to five-fold more than that of the barnyardgrass roots, and the dry weight of the rice roots was greater in the allelopathic rice PI312777 than in the nonallelopathic rice Liaojing-9 (data not shown).

On the other hand, the dynamic response of root proliferation of E. crus-galli is due to rice allelopathy $[23,24,27,37]$. For instance, the allelopathic rice PI312777 can release allelochemicals into the soil and inhibit the growth of paddy weeds [24,27]. The allelopathic rice Huagan-3 can interfere with the growth of penoxsulam-resistant barnyardgrass through allelochemical-mediated root-root interaction [33]. In addition, decline of barnyardgrass root growth is due to shift in microbial diversity and community structure shaped by the root exudates of the allelopathic rice [26]. In summary, these findings determine that the allelopathic rice varieties interfere with barnyardgrass performance by altering root traits [38], suggesting that root recognition could be one of important root behavioural strategies in crop-weed allelopathic interactions.

\subsection{Impact of Root Recognition on Nutrient Foraging and Competition}

Our results clearly showed that the root foraging precision and competition intensity index of barnyardgrass were reduced by neighbouring allelopathic roots, indicating the important role of root recognition on nutrient foraging and competition through altering morphological and architectural traits (Figures 2 and 3). For instance, it is not specific root length (SRL) but root tissue density (RTD) which exhibited a more sensitive response to the allelopathic root neighbour (Figure 2b), confirming RTD as a key functional trait in affecting species interactions [39]. RTD is regarded as an indicator of a plant adaptive strategy to environmental conditions, due to association with many critical aspects of plant growth and survival $[40,41]$. In addition, our results showed a negative correlation between topological index and foraging precision and competition intensity index (Figure 4), which highlights that rice allelopathy plays a key role affecting the barnyardgrass behaviour, shedding light on a direct linkage to root form and function to further better understand the mechanisms of root-root interactions.

A possible mechanism underlying monoculture and mixed culture root-root interactions is chemical communication within the rhizosphere. For instance, the plant hormones of ethylene [42], strigolactone [43], jasmonic acid and salicylic acid [44], have been demonstrated to play important roles in root recognition through shift in the root traits of morphology and architecture. Consequently, plant growth is affected by the root exudates of neighbours, which play key roles in inducing allelopathic activity [21,24]. The roots growth can be directly inhibited or facilitated by allelochemicals released from neighbouring roots $[24,27,45]$. The presence of competitive weeds and their root exudates can increase the production of the rice allelochemicals, momilactones and flavone [26,27,37,46-48], resulting in enhancement in rice allelopathy by the chemical components in barnyardgrass root exudates [23]. Consequently, the induced allelopathic activity may provide a competitive advantage for crops through suppression of the growth of neighbouring weeds, highlighting that plant competitor detection and allelochemical elicitation play pivotal roles in regulating crop-weed interactions. 
On the other hand, roots growth is indirectly affected by root-soil microbe interaction mediated by root exudates, because the root exudates can increase or decrease soil nutrient availability by altering the rhizosphere microbial community and the chemical properties $[27,37,48,49]$. These effects can in turn influence outcomes of resource competition between plants and neighbours [21,48]. This study has determined that barnyardgrass root proliferation and morphology can respond to root chemical cues from rice seedlings. These results support other studies where it was found that root exudates mediated root recognition behaviour in Arabidopsis thaliana [34] and in Deschampsia caespitosa [16]. It should be noted that this study only shows barnyardgrass recognition response to allelopathic rice in a greenhouse experiment, and thus further investigation into the role of root recognition in the response to allelopathic rice under field conditions with fertilization regimes is needed.

\section{Materials and Methods}

\subsection{Plant and Soil Sample}

The O. sativa varieties of PI312777 and Liaojing-9 were used in this study. PI312777, an allelopathic rice line, was originally identified from the USDA-ARS (United States Department of Agriculture Agricultural Research Service) rice germplasm collection and exhibited weed suppression in both US and Chinese paddy fields. Liaojing-9 is a commercial cultivar in Northeast China and does not have allelopathic traits [26,49]. Plants of E. caudata, E. colona (L.) Link, E. crus-galli (L.) beauv, E. crus-galli var. mitis (Pursh) Peterm and E. crus-galli var. zelayensis (H. B. K) Hitehe were used in this study. The seeds of E. caudata and E. crus-galli (L.) beauv were collected from paddy field at National Field Research Station of Shenyang Agroecosystems, Shenyang, Liaoning province $\left(41^{\circ} 31^{\prime} \mathrm{N}, 123^{\circ} 24^{\prime} \mathrm{E}\right)$. The other three varieties were obtained from the weed laboratory at the Institute of Plant Protection, Jiangsu Academy of Agricultural Sciences, Nanjing, Jiangsu province.

The soils were classified as Mollisol, collected from 0 to $20 \mathrm{~cm}$ depth at Heilongjiang Academy of Agricultural Sciences in Harbin, Heilongjiang province. The soils were air-dried and sieved $(<5 \mathrm{~mm})$ after removing plant fragments. The soil contained $1.84 \%$ organic $\mathrm{C}, 0.14 \% \mathrm{~N}, 43 \%$ sand, $22 \%$ silt, and $35 \%$ clay, and had a $\mathrm{pH}$ of 6.8 (soil:water ratio, 1:2.5) and a C:N ratio of 12.8 .

\subsection{Plant Growth, Sampling and Traits Calculating}

The barnyardgrass-rice mixed culture experiment was conducted in a greenhouse at $20-30{ }^{\circ} \mathrm{C}$ night and daytime temperatures and $70-90 \%$ relative humidity maintained during the growing season in 2016. The experiments were conducted in a completely randomized design with five replicates for each treatment or control. A series of plastic pots $(20 \times 5 \mathrm{~cm})$ containing $300 \mathrm{~g}$ of soil was used for the experiment. In total, two pre-germinated seeds were sown and spaced uniformly in each pot. Treatments for barnyardgrass included barnyardgrass mixed with allelopathic rice (BYG + AR), barnyardgrass mixed with nonallelopathic rice (BYG + NAR) and barnyardgrass monoculture (BYG + BYG). Barnyardgrass monocultures served as the controls. Pots were placed in the greenhouse, watered daily and randomized once a week. Seedlings were harvested after four weeks and their shoots and roots were collected for analysis of biomass and morphological traits.

Root traits were calculated according to the following procedure. Briefly, the seedlings were placed on a $0.5 \mathrm{~mm}$ screen, soaked and washed to separate the roots from the soil, coding each root as belonging to either rice or barnyardgrass. All visible roots were removed from the screens by hand, rinsed with deionized water and stored at $4{ }^{\circ} \mathrm{C}$ until further processing. The roots were separated from neighbour roots using fine forceps. Clean, unbroken sections of roots were chosen for morphological analysis. The following morphological traits were measured with WINRHIZO image analysis software (Regent Instruments Inc., Quebec City, QC, Canada): root biomass (RM), total root length (Length), root tips (Tips), total surface area (SA), total root volume (RV), and external path length (Pe). All root characteristics are listed in Table 2. 
Table 2. Definitions of individual root traits, nutrient foraging behavior characteristics and root architecture characteristics.

\begin{tabular}{|c|c|c|}
\hline Individual Root Characteristics & Abbreviation & Definition \\
\hline Root biomass & $\mathrm{RM}$ & Total root dry biomass (mg plant ${ }^{-1}$ ) \\
\hline Root allocation & $\mathrm{Ra}$ & Ratio of root mass to total mass (\%) \\
\hline Root tips & Tips & The number of root tips \\
\hline Specific root length & SRL & Length per unit root dry biomass $\left(\mathrm{m} \mathrm{g}^{-1}\right)$ \\
\hline Nutrient foraging behaviour characteristics & Symbol & Definition \\
\hline Root foraging precision & Precision & $\begin{array}{l}\text { Precision was measured by 1-RMt/RMc, where RMt is the root } \\
\text { biomass of barnyardgrass in a mixed culture pot, and RMc is the } \\
\text { corresponding value for barnyardgrass in a monoculture } \\
\text { seedling pots(control). Greater ratios are considered to represent } \\
\text { higher precision }\end{array}$ \\
\hline Competition intensity index & $\mathrm{CII} r$ & $\mathrm{CII} r=($ Broot-c - Broot-t $) / \mathrm{X}$, for evaluating root competition \\
\hline Topological characteristics & Symbol & Definition \\
\hline Magnitude $^{1}$ & $\mu$ & The number of root tips (exterior links) in the system \\
\hline External path length ${ }^{1}$ & $\mathrm{Pe}$ & $\begin{array}{l}\text { The sum of the number of links in all paths from each external } \\
\text { link to the base link }\end{array}$ \\
\hline Topological index ${ }^{1}$ & TI & $\begin{array}{l}\text { A way to quantify branching pattern using the relationship } \\
\text { between } \log 10 \text { external path length and } \log 10 \text { magnitude, } \\
\mathrm{TI}=\log 10(\mathrm{Pe}) / \log 10(\mu)\end{array}$ \\
\hline
\end{tabular}

${ }^{1}$ Ref. [50].

\subsection{Data Analysis}

Root architecture trait was quantified using the topological index, and nutrient foraging behaviour was measured using root foraging precision. Additionally, we further assessed the magnitude of the potential competition between seedlings using a competition intensity index [51] (for explanations, see Table 2).

The normality of the root variables and the homogeneity of the group variances were evaluated with Lilliefors and Shapiro-Wilk tests (for normality), and the F and Levene tests (for homogeneity), respectively. An analysis of variance (ANOVA) was performed for root traits with species and allelopathy as two factors. Simple linear regressions were used to determine the relationships between root traits, root architecture trait (TI) and root foraging precision and competition. Differences among treatments were further investigated using Tukey's comparisons at the $p<0.05$ level. All analyses were performed using Statistica 8 package (StatSoft Inc., Tulsa, OK, USA).

\section{Conclusions}

Root recognition and allelopathy in plant-plant interaction and their consequences for plant competition and performance have important implications in natural ecosystems and agricultural ecosystems. This study showed that barnyardgrass plants exhibited opposite modifications of root biomass fraction and tissue density when grown with the root neighbours of the allelopathic or the nonallelopathic rice. Furthermore, nutrient foraging and competition of barnyardgrass were affected by allelopathy-mediated root recognition, suggesting that rice allelopathy can be considered as a new mechanism of root recognition in barnyardgrass-rice interaction. These findings provide new evidence that these plants can discriminate rice identity with allelopathy. However, additional studies involving the mechanism of regulating these allelopathy-mediated responses to root neighbours in crop-weed interactions are required. 
Acknowledgments: Authors wish to thank Feike A. Dijkstra for English editing help and three anonymous reviewers for their constructive comments. This work was financially supported the National Natural Science Foundation of China (NSFC Nos. 41271319, 40971159).

Author Contributions: P.W. conceived and designed the experiments; T.Z. and B.F. performed the experiments; T.Z. analyzed the data; T.Z. and P.W. wrote the paper.

Conflicts of Interest: The authors declare no conflict of interest.

\section{References}

1. Hutchings, M.J.; de Kroon, H. Foraging in plants: The role of morphological plasticity in resource acquisition. Adv. Ecol. Res. 1994, 25, 159-238. [CrossRef]

2. Hodge, A. The plastic plant: Root responses to heterogeneous supplies of nutrients. New Phytol. 2004, 162, 9-24. [CrossRef]

3. Mommer, L.; Visser, E.J.; van Ruijven, J.; de Caluwe, H.; Pierik, R.; de Kroon, H. Contrasting root behaviour in two grass species: A test of functionality in dynamic heterogeneous conditions. Plant Soil 2011, 344, 347-360. [CrossRef]

4. Robinson, D. The responses of plants to non-uniform supplies of nutrients. New Phytol. 1994, 127, 635-674. [CrossRef]

5. Dudley, S.A.; File, A.L. Kin recognition in an annual plant. Biol. Lett. 2007, 3, 435-438. [CrossRef] [PubMed]

6. Murphy, G.P.; Dudley, S.A. Kin recognition: Competition and cooperation in Impatiens (Balsaminaceae). Am. J. Bot. 2009, 96, 1990-1996. [CrossRef] [PubMed]

7. Depuydt, S. Arguments for and against self and non-self root recognition in plants. Front. Plant Sci. 2014, 5, 614. [CrossRef] [PubMed]

8. Faget, M.; Nagel, K.A.; Walter, A.; Herrera, J.M.; Jahnke, S.; Schurr, U.; Temperton, V.M. Root-root interactions: Extending our perspective to be more inclusive of the range of theories in ecology and agriculture using in-vivo analyses. Ann. Bot. 2013, 112, 253-266. [CrossRef] [PubMed]

9. Maina, G.G.; Brown, J.S.; Gersani, M. Intra-plant versus inter-plant root competition in beans: Avoidance, resource matching or tragedy of the commons. Plant Ecol. 2002, 160, 235-247. [CrossRef]

10. Gersani, M.; Brown, J.S.; O’Brien, E.E.; Maina, G.M.; Abramsky, Z. Tragedy of the commons as a result of root competition. J. Ecol. 2001, 89, 660-669. [CrossRef]

11. Falik, O.; de Kroon, H.; Novoplansky, A. Physiologically-mediated self/non self root discrimination in Trifolium repens has mixed effects on plant performance. Plant Signal. Behav. 2006, 1, 116-121. [CrossRef] [PubMed]

12. Semchenko, M.; Hutchings, M.J.; John, E.A. Challenging the tragedy of the commons in root competition: Confounding effects of neighbour presence and substrate volume. J. Ecol. 2007, 95, 252-260. [CrossRef]

13. Markham, J.; Halwas, S. Effect of neighbour presence and soil volume on the growth of Andropogon gerardii Vitman. Plant Ecol. Divers. 2011, 4, 265-268. [CrossRef]

14. De Kroon, H. How do roots interact? Science 2007, 318, 1562-1563. [CrossRef] [PubMed]

15. Semchenko, M.; John, E.A.; Hutchings, M.J. Effects of physical connection and genetic identity of neighbouring ramets on root-placement patterns in two clonal species. New Phytol. 2007, 176, 644-654. [CrossRef] [PubMed]

16. Semchenko, M.; Saar, S.; Lepik, A. Plant root exudates mediate neighbor recognition and trigger complex behavioural changes. New Phytol. 2014, 204, 631-637. [CrossRef] [PubMed]

17. Schenk, H.J.; Callaway, R.M.; Mahall, B.E. Spatial root segregation: Are plants territorial? Adv. Ecol. Res. 1999, 28, 145-180. [CrossRef]

18. Falik, O.; Reides, P.; Gersani, M.; Novoplansky, A. Self/non-self discrimination in roots. J. Ecol. 2003, 91, 525-531. [CrossRef]

19. Caffaro, M.M.; Vivanco, J.M.; Botto, J.; Rubio, G. Root architecture of Arabidopsis, is affected by competition with neighbouring plants. Plant Growth Regul. 2013, 70, 141-147. [CrossRef]

20. Fang, S.; Clark, R.T.; Zheng, Y.; Iyer-Pascuzzi, A.S.; Weitz, J.S.; Kochian, L.V.; Edelsbrunner, H.; Liao, H.; Benfey, P.N. Genotypic recognition and spatial responses by rice roots. Proc. Natl. Acad. Sci. USA 2013, 110, 2670-2675. [CrossRef] [PubMed] 
21. Bais, H.P.; Weir, T.L.; Perry, L.G.; Gilroy, S.; Vivanco, J.M. The role of root exudates in rhizosphere interactions with plants and other organisms. Annu. Rev. Plant Biol. 2006, 57, 233-266. [CrossRef] [PubMed]

22. Metlen, K.L.; Aschehoug, E.T.; Callaway, R.M. Plant behavioural ecology: Dynamic plasticity in secondary metabolites. Plan Cell Environ. 2009, 32, 641-653. [CrossRef] [PubMed]

23. Kato-Noguchi, H. The chemical cross talk between rice and barnyardgrass. Plant Signal. Behav. 2011, 6, 1207-1209. [CrossRef]

24. Kong, C.H.; Liang, W.J.; Xu, X.H.; Hu, F.; Wang, P. Release and activity of allelochemicals from allelopathic rice seedlings. J. Agric. Food Chem. 2004, 52, 2861-2865. [CrossRef] [PubMed]

25. Farooq, M.; Jabran, K.; Cheema, Z.A.; Wahid, A.; Siddique, K.H.M. The role of allelopathy in agricultural pest management. Pest Manag. Sci. 2011, 67, 493-506. [CrossRef] [PubMed]

26. Kong, C.H.; Wang, P.; Zhao, H.; Xu, X.H.; Zhu, Y.D. Impact of allelochemical exuded from allelopathic rice on soil microbial community. Soil Biol. Biochem. 2008, 40, 1862-1869. [CrossRef]

27. Kato-Noguchi, H.; Ino, T. Rice seedlings release momilactone B into the environment. Phytochemistry 2003, 63, 551-554. [CrossRef]

28. Khanh, T.D.; Xuan, T.D.; Chung, I.M. Rice allelopathy and the possibility for weed management. Ann. Appl. Biol. 2007, 151, 325-339. [CrossRef]

29. Xuan, T.D.; Chung, M.I.; Khanh, T.D.; Tawata, S. Identification of phytotoxic substances from early growth of barnyard grass (Echinochloa crusgalli) root exudates. J. Chem. Ecol. 2006, 32, 895-906. [CrossRef] [PubMed]

30. Bajwa, A.A.; Jabran, K.; Shahid, M.; Ali, H.H.; Chauhan, B.S. Eco-biology and management of Echinochloa crus-galli. Crop Protect. 2015, 75, 151-162. [CrossRef]

31. Beckie, H.J. Herbicide-resistant weeds: Management tactics and practices. Weed Technol. 2006, $20,793-814$. [CrossRef]

32. Sun, B.; Wang, P.; Kong, C.H. Plant-soil feedback in the interference of allelopathic rice with barnyardgrass. Plant Soil 2014, 377, 309-321. [CrossRef]

33. Yang, X.F.; Kong, C.H.; Yang, X.; Li, Y.F. Interference of allelopathic rice with penoxsulam-resistant barnyardgrass. Pest. Manag. Sci. 2017, 73, 2310-2317. [CrossRef] [PubMed]

34. Biedrzycki, M.L.; Jilany, T.A.; Dudley, S.A.; Bais, H.P. Root exudates mediate kin recognition in plants. Commun. Integr. Biol. 2010, 3, 28-35. [CrossRef] [PubMed]

35. Jacob, C.E.; Tozzi, E.; Willenborg, C.J. Neighbour presence, not identity, influences root and shoot allocation in pea. PLoS ONE 2017, 12, e0173758. [CrossRef] [PubMed]

36. Lamb, E.G.; Kembel, S.W.; Cahill, J.F. Shoot, but not root, competition reduces community diversity in experimental mesocosms. J. Ecol. 2009, 97, 155-163. [CrossRef]

37. Kato-Noguchi, H. Barnyard grass-induced rice allelopathy and momilactone B. J. Plant Physiol. 2011, 168, 1016-1020. [CrossRef] [PubMed]

38. Yang, X.F.; Kong, C.H. Interference of allelopathic rice with paddy weeds at the root level. Plant Biol. 2017, 19, 584-591. [CrossRef] [PubMed]

39. Birouste, M.; Zamora-Ledezma, E.; Bossard, C.; Pérez-Ramos, I.M.; Roumet, C. Measurement of fine root tissue density: A comparison of three methods reveals the potential of root dry matter content. Plant Soil 2014, 374, 299-314. [CrossRef]

40. Westoby, M. A leaf-height-seed (LHS) plant ecology strategy scheme. Plant Soil 1998, 199, $213-227$. [CrossRef]

41. Craine, J.M.; Froehle, J.; Tilman, D.G.; Wedin, D.A.; Chapin, F.S., III. The relationships among root and leaf traits of 76 grassland species and relative abundance along fertility and disturbance gradients. Oikos 2001, 93, 274-285. [CrossRef]

42. Pierik, R.; Visser, E.J.W.; de Kroon, H.; Voesenek, L.A.C.J. Ethylene is required in tobacco to successfully compete with proximate neighbours. Plant Cell Environ. 2003, 26, 1229-1234. [CrossRef]

43. Kapulnik, Y.; Koltai, H. Strigolactone involvement in root development, response to abiotic stress, and interactions with the biotic soil environment. Plant Physiol. 2014, 166, 560-569. [CrossRef] [PubMed]

44. You, L.X.; Wang, P.; Kong, C.H. The levels of jasmonic acid and salicylic acid in a rice-barnyardgrass coexistence system and their relation to rice allelochemicals. Biochem. Syst. Ecol. 2011, 39, 491-497. [CrossRef]

45. Heidarzade, A.; Esmaeili, M.; Pirdashti, H. Common allelochemicals in root exudates of Barnyardgrass (Echinochloa crusgalli L.) and inhibitory potential against rice (Oryza sativa) cultivars. Int. Res. J. Appl. Basic Sci. 2012, 3, 11-17. 
46. Kato-Noguchi, H.; Ino, T. The chemical-mediated allelopathic interaction between rice and barnyard grass. Plant Soil 2013, 370, 267-275. [CrossRef]

47. Kato-Noguchi, H.; Peters, R.J. The role of momilactones in rice allelopathy. J. Chem. Ecol. 2013, 39, $175-185$. [CrossRef] [PubMed]

48. Bertin, C.; Yang, X.; Weston, L.A. The role of root exudates and allelochemicals in the rhizosphere. Plant Soil 2003, 256, 67-83. [CrossRef]

49. Wang, P.; Zhang, X.; Kong, C.H. The response of allelopathic rice growth and microbial feedback to barnyardgrass infestation in a paddy field experiment. Eur. J. Soil Biol. 2013, 56, 26-32. [CrossRef]

50. Fitter, A.H. An architectural approach to the comparative ecology of plant-root systems. New Phytol. 1987, 106, 61-77. [CrossRef]

51. Fort, F.; Cruz, P.; Jouany, C.; Field, K. Hierarchy of root functional trait values and plasticity drive early-stage competition for water and phosphorus among grasses. Funct. Ecol. 2014, 28, 1030-1040. [CrossRef]

2018 by the authors. Licensee MDPI, Basel, Switzerland. This article is an open access article distributed under the terms and conditions of the Creative Commons Attribution (CC BY) license (http:// creativecommons.org/licenses/by/4.0/). 